

VOLUME 50 PART 4 JULY 2016

ISSN 0026-749X

\title{
CELEBRATING 50 YEARS
}

Special Issue:

Love, Marriage, and Intimate Citizenship in Contemporary China and India

Guest Editors:

Dr Henrike Donner

Dr Gonçalo Santos 


\section{assogiate editor: Norbert Peabody, University of Cambridge}

\section{EXEGUTIVE GOMMITTEE}

Seema Alavi, University of Delhi

Timothy Harper, University of Cambridge

Caroline Humphrey, University of Cambridge

Heonik Kwon, University of Cambridge
James Laidlaw, University of Cambridge

Charles Schencking, University of Hong Kong

Hans Van de Ven, University of Cambridge

David Washbrook, University of Cambridge

\section{EDITORIAL BOARD}

Shahid Amin, University of Delhi

Sunil Amrith, Harvard University

Sumantra Bose, The London School of Economics \& Political Science

Uradyn E. Bulag, University of Cambridge

Prasenjit Duara, National University of Singapore

Richard Eaton, University of Arizona

Wang Gungwu, National University of Singapore

Farhat Hasan, University of Delhi

Engseng Ho, Duke University

Sunil Khilnani, King's College London

Victor T. King, University of Leeds

Barak Kushner, University of Cambridge

Michael Laffan, Princeton University

Victor Lieberman, University of Michigan

Claude Markovits, Centre National de la

Recherche Scientifique, Paris

\author{
Magnus Marsden, University of Sussex \\ Rana Mitter, University of Oxford \\ Deepak Nayyar, Jawaharlal Nehru University \\ Tirthankar Roy, University of London \\ Samita Sen, Jadavpur University \\ Ornit Shani, University of Haifa \\ Naoko Shimazu, Yale-NUS College, Singapore \\ Eric Tagliacozzo, Cornell University \\ Robert Travers, Cornell University \\ C. J. W.-L. Wee, Nanyang Technological \\ University \\ Thongchai Winichakul, University \\ of Wisconsin-Madison \\ Tan Tai Yong, National University of \\ Singapore \\ Yangwen Zheng, University of Manchester
}

\section{EMERITUS EDITOR \\ Gordon Johnson, University of Cambridge}

Modern Asian Studies (ISSN 0026-749x) is published six times a year by Cambridge University Press, Journals Fulfilment Department, UPH, Shaftesbury Road, Cambridge CB2 8BS, UK, and 1 Liberty Plaza, Floor 20, New York, NY 10006, USA. The subscription (excluding VAT but including delivery by air where appropriate), plus electronic access to institutional subscribers, to volume 50, 2016 is $£ 500$ net (US $\$ 878$ in the USA, Canada, and Mexico) for institutions. Individuals who order direct from the publishers and certify that the journal is for their personal use may subscribe at a reduced rate of $\mathcal{E}^{80}$ for print (US $\$ 137$ in the USA, Canada, and Mexico). Single parts cost $\AA_{92}$ (US $\$ 162$ in the USA, Canada, and Mexico). The electronic only price available to institutional subscribers is $\mathcal{E}_{423}$ (\$740 in the USA, Canada, and Mexico). All orders must be accompanied by payment. EU subscribers (outside the UK) who are not registered for VAT should add VAT at their country's rate. VAT registered subscribers should provide their VAT registration number. Japanese prices for institutions are available from Kinokuniya Company Ltd, P. O. Box 55, Chitose, Tokyo I56, Japan.

Periodicals postage paid at New York, New York and additional mailing offices. POSTMASTER: send address changes in the USA, Canada, and Mexico to MODERN ASIAN STUDIES, 1 Liberty Plaza, Floor 20, New York, NY 10006, USA

Information on Modern Asian Studies and all other Cambridge journals can be accessed via www.journals.cambridge.org

This journal issue has been printed on FSC-certified paper and cover board. FSC is an independent, non-governmental, not-for-profit organization established to promote the responsible management of the world's forests. Please see www.fsc.org for information. 